University of Nebraska - Lincoln

DigitalCommons@University of Nebraska - Lincoln

Faculty Publications - Textiles, Merchandising and Fashion Design

Textiles, Merchandising and Fashion Design,

Department of

$7-2010$

\title{
Non-traditional lightweight polypropylene composites reinforced with milkweed floss
}

Narendra Reddy

University of Nebraska - Lincoln, nreddy3@unl.edu

Yiqi Yang

University of Nebraska - Lincoln, yyang2@unl.edu

Follow this and additional works at: https://digitalcommons.unl.edu/textiles_facpub

Part of the Art and Design Commons

Reddy, Narendra and Yang, Yiqi, "Non-traditional lightweight polypropylene composites reinforced with milkweed floss" (2010). Faculty Publications - Textiles, Merchandising and Fashion Design. 24. https://digitalcommons.unl.edu/textiles_facpub/24

This Article is brought to you for free and open access by the Textiles, Merchandising and Fashion Design, Department of at DigitalCommons@University of Nebraska - Lincoln. It has been accepted for inclusion in Faculty Publications - Textiles, Merchandising and Fashion Design by an authorized administrator of DigitalCommons@University of Nebraska - Lincoln. 


\title{
Non-traditional lightweight polypropylene composites reinforced with milkweed floss
}

\author{
Narendra Reddy ${ }^{1}$ and Yiqi Yang ${ }^{1,2,3}$ \\ 1. Department of Textiles, Clothing and Design, University of Nebraska-Lincoln \\ 2. Department of Biological Systems Engineering, University of Nebraska-Lincoln \\ 3. Nebraska Center for Materials and Nanoscience, University of Nebraska-Lincoln \\ Corresponding author - Yiqi Yang, Department of Textiles, Clothing and Design, 234 HECO Building, \\ University of Nebraska-Lincoln, Lincoln, NE 68583-0802, USA; email yyang2@unl.edu
}

\begin{abstract}
Lightweight composites are preferred for automotive applications due to the weight restrictions and also due to the presence of inherent voids that can enhance the sound absorption of these composites. The density of the reinforcing materials plays a crucial role in such lightweight composites. Milkweed is a unique natural cellulose fiber that has a completely hollow center and low density $\left(0.9 \mathrm{~g} \mathrm{~cm}^{-3}\right)$ unlike any other natural cellulose fiber. The low density of milkweed fibers will allow the incorporation of higher amounts of fiber per unit weight of a composite, which is expected to lead to lightweight composites with better properties. Polypropylene (PP) composites reinforced with milkweed fibers have much better flexural and tensile properties than similar PP composites reinforced with kenaf fibers. Milkweed fiber-reinforced composites have much higher strength but are stiffer than kenaf fiber-reinforced PP composites. Increasing the proportion of milkweed in the composites from 35 to $50 \%$ increases the flexural strength but decreases the tensile strength. The low density of milkweed fibers allows the incorporation of higher amounts of fibers per unit weight of the composites and hence provides better properties compared to composites reinforced with common cellulose fibers with relatively high density. This research shows that low-density reinforcing materials can more efficiently reinforce lightweight composites.
\end{abstract}

Keywords: milkweed, cellulose fibers, composites, low weight, polypropylene

\section{Introduction}

The density of reinforcing fibers plays a crucial role in determining the properties of composites containing the fibers, especially in lightweight composites used for automotive applications. ${ }^{1-5}$ For lightweight composites, the density of the composite is much lower than the combined densities of the reinforcing and matrix polymers leading to the creation of inherent voids. The presence of voids results in lightweight composites with inferior mechanical properties compared to similar consolidated composites. Although conventional natural fibers such as jute and kenaf have been widely used to develop consolidated composites, these traditional fibers have relatively high densities $\left(1.5 \mathrm{~g} \mathrm{~cm}^{-3}\right)$ and are therefore not preferred for lightweight composites.

It is preferable to use reinforcing materials with low densities for lightweight composites because larger amounts of lower density materials can be added into the composites compared to using the same weight of high-density materials. The larger amounts of lightweight materials will decrease the number of voids in the composites and therefore improve the mechanical properties of the composites. Chicken feathers $\left(0.9 \mathrm{~g} \mathrm{~cm}^{-3}\right)$ and biomass such as cornhusks (ca $1.2 \mathrm{~g}$ $\mathrm{cm}^{-3}$ ) that have low density have been used as reinforcement for lightweight composites. ${ }^{2-5}$ Although their relatively high density restricts the use of natural cellulose fibers in lightweight automotive composites, natural cellulose fibers extracted from various biomasses such as cotton stalks and used as reinforcement in lightweight composites provide similar mechanical properties to polypropylene (PP) composites as jute fibers. ${ }^{6}$

Milkweed floss is a unique natural fiber with a low density of about $0.9 \mathrm{~g} \mathrm{~cm}^{-3}$ due to the presence of a completely hollow center. ${ }^{7,8}$ No other known natural cellulose fiber has such a low density or such a hollow center. Because of its low density, milkweed floss has been used as filling material in jackets to replace goose down. ${ }^{9}$ In addition, milkweed is a plant that was once considered a viable crop and its components useful for various applications. ${ }^{10,11}$ For instance, the bast or stem of the plant are reportedly suitable for producing natural rubber and the seeds of the plant are used as sources of oil. ${ }^{12,13}$ The fiber (floss) in the plant has been studied for use in textiles and filling materials. ${ }^{8,14,15}$ Efforts have also been made to process milkweed floss as a natural cellulose fiber and develop textiles. ${ }^{14,} 15$ However, the low elongation, poor strength and relatively short lengths of milkweed make the floss unsuitable for processing on textile machinery to develop $100 \%$ milkweed floss products. Milkweed floss has been blended with cotton and successfully processed to develop yarns. ${ }^{14,} 15$ Previously, injectionmolded composites have been developed by blending giant milkweed floss with PP. ${ }^{16}$ It was reported that milkweed floss had poor interfacial adhesion with PP and a coupling agent was necessary to obtain composites with good properties. ${ }^{16}$ 
In the research reported here, we have developed lightweight composites using common milkweed floss as the reinforcing fiber and PP as the matrix polymer. The composition and structure of the milkweed floss was determined and the effects of the concentration of the milkweed floss and density of the composites on tensile, flexural and impact resistance properties were studied. Since most of the composites reported in the open literature are consolidated composites, we compared the properties of the milkweed composites with similar lightweight composites reinforced with kenaf fiber rather than using literature data available for consolidated composites. Kenaf was chosen for comparison because it is commonly used in composites and is considered to be a potential alternative fiber crop in the USA. PP was chosen as the matrix material since it has low density and melting point and is an inexpensive polymer.

\section{Materials and Methods}

\section{Fiber characterization}

Milkweed floss was purchased from Natural Fibers Corporation (Ogallala, NE). The milkweed floss obtained was characterized for its structure and properties. However, the milkweed floss fibers are very fine and brittle and it was not possible to determine the tensile properties of the milkweed floss in our laboratory. PP fibers were supplied by Drake Extrusion (Martinsville, VA). The PP fibers were of 3 denier, $75 \mathrm{~mm}$ long and with a breaking tenacity of $4 \mathrm{~g}$ denier $^{-1}$. The melting temperature $\left(T_{m}\right)$ of the fibers was $162{ }^{\circ} \mathrm{C}$ with a melt flow index of $20 \mathrm{~g}(10 \mathrm{~min})^{-1}$ at $230^{\circ} \mathrm{C}$. The diameter of the fibers was $22 \mu \mathrm{m}$, the density was $0.90 \mathrm{~g} \mathrm{~cm}^{-3}$ and the crystallinity was $50 \%$. Kenaf fibers were supplied by Bast Fibers LLC (Cresskill, NJ). The kenaf fibers had a denier of 16, length of $80 \mathrm{~mm}$, average breaking tenacity of $3.0 \mathrm{~g} \mathrm{denier}^{-1}$, breaking elongation of $1 \%$ and modulus of $330 \mathrm{~g} \mathrm{denier}^{-1}$.

\section{Composition}

The composition of the milkweed fibers was measured in terms of the cellulose and lignin content. Cellulose in the fibers was measured as acid detergent fiber (ADF) according to AOAC method 973.18. Lignin in the fibers was measured as klason lignin according to ASTM method D1106-96. Three replications were done for each compositional analysis and values of average \pm one standard deviation are reported.

\section{Morphology}

The morphology of the fibers was studied using variablepressure scanning electron microscopy (VP-SEM). The fibers were placed on conductive adhesive tapes, sputtercoated with gold palladium and observed in the instrument at a voltage of $20-25 \mathrm{kV}$.

\section{Physical structure}

The physical structure of the fibers in terms of the percentage crystallinity was determined using XRD. The milkweed floss was powdered in a Wiley mill to pass through a 250 $\mu \mathrm{m}$ mesh and the powder was made into a pellet using a die and pressing in a hydraulic press operated at ca 20000 psi $(140 \mathrm{MPa})$. The X-ray measurements were obtained using a Rigaku diffractometer with Bragg-Brentano parafocusing geometry, a diffracted beam monochromator and a copper target X-ray tube set to $40 \mathrm{kV}$ and $30 \mathrm{~mA}$. The percentage crystallinity of the fibers was calculated as the ratio of the area under the crystalline peak to the total area obtained by integration using the software program MICROCAL ORIGIN.

\section{Density}

The density of the milkweed fibers was determined using the sink-float method with xylene and carbon tetrachloride. ${ }^{17}$

\section{Composite preparation}

To obtain a fair comparison with the milkweed fibers, the kenaf fibers were cut to the same length as the milkweed fibers (about $2 \mathrm{~cm}$ ) and used to develop the composites. A schematic of the process used to develop the milkweed- and kenaf-reinforced PP composites is shown in Figure 1. The milkweed floss or kenaf fibers and PP fibers were separately opened on a laboratory carding machine. The webs of the milkweed/kenaf fibers were combined with the PP fiber webs in the required weight ratio and the webs were then carded together. The blends were carded four times to achieve uniform mixing. The homogenous webs obtained were cut into sizes of $10 \times 12$ inches $(254 \times 305 \mathrm{~mm})$. Several layers of these webs were used to obtain the required weight per unit area. Each rectangular web of fibers was laid on top, perpendicular to each other so that the fibers in each layer were oriented at $90^{\circ}$ to the next layer. The stacked layers of webs were placed between two aluminium foils and then compression molded in a Carver press at $380{ }^{\circ} \mathrm{F}$ for $140 \mathrm{~s}$. The temperature and time of processing the composites with PP matrix were optimized in our previous research. ${ }^{2,3}$ The thickness of the composites was controlled using metal spacers to make composites with a density of $0.47 \mathrm{~g} \mathrm{~cm}^{-3}$, necessary for many applications. After heating, the press was immediately cooled with cold water and the composites were collected. Three composites were prepared for each condition and at least two samples were cut from each composite for a total of six specimens for each test.

\section{Composite characterization}

The composites were conditioned in a standard testing atmosphere of $21{ }^{\circ} \mathrm{C}$ and $65 \%$ relative humidity for at least $24 \mathrm{~h}$ before testing. Flexural, tensile and impact resistance tests were conducted using two samples from each of the three composites for each condition studied. Flexural tests were done on samples measuring $7.6 \mathrm{~cm} \times 20.3 \mathrm{~cm}$. Tensile tests were done on dog-bone shaped samples having a length

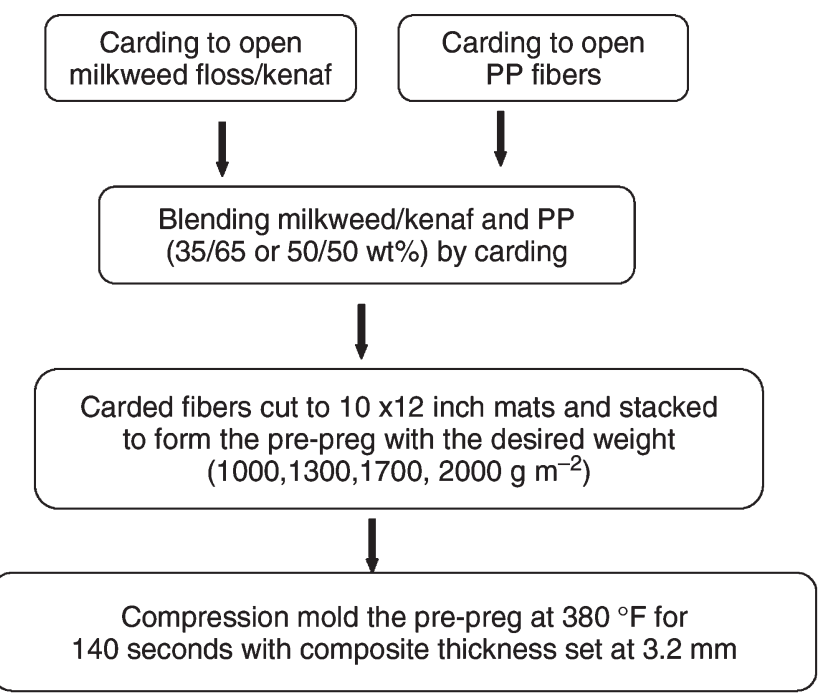

Figure 1. Schematic of the process used to fabricate the milkweed floss- and kenaf-reinforced PP composites. 
Table 1. Comparison of the composition, morphology and physical structure of milkweed floss fibers with kenaf

\begin{tabular}{lll}
\hline & Milkweed floss & \\
\hline Composition: cellulose (\%) & $52.1 \pm 2.1$ & Kenaf ${ }^{\mathrm{b}}$ \\
\hline Composition: lignin (\%) & $21.3 \pm 2.6$ & $6-66$ \\
Fiber length (mm) & $14.2 \pm 3.0$ & $2.2-7.8$ \\
Crystallinity (\%) & $32 \pm 1.7$ & - \\
Moisture regain (\%) & $10.6 \pm 0.7$ & 9.8 \\
\hline
\end{tabular}

a. Errors indicate \pm one standard deviation.

b. Data for kenaf taken from Morrison et al. ${ }^{24}$ and Tao et al. ${ }^{25,26}$

of $165 \mathrm{~mm}$, the width of the wide section being $19 \mathrm{~mm}$ and that of the narrow section being $13 \mathrm{~mm}$. Test specimens for impact resistance were of $63.5 \mathrm{~mm} \times 10.16 \mathrm{~mm}$ with a notch cut perpendicular to the cross-section of the samples.

Flexural tests were done according to ASTM standard D790-03 using an MTS (model Q Test 10, MTS Corporation, Eden Prairie, MN) tensile tester equipped with a $500 \mathrm{~N}$ load cell. The crosshead speed used was $10 \mathrm{~mm} \mathrm{~min}^{-1}$. Tensile tests were performed using an Instron tensile tester (model 4000, Instron, Norwood, MA) according to ASTM standard D638-03. The crosshead speed was $5 \mathrm{~mm} \mathrm{~min}^{-1}$. The impact resistance of the composites was tested according to ASTM standard D256 using an Izod impact tester (Cometech Testing Company Ltd, Taiwan). Six samples from three different composites were tested for the flexural, tensile and impact resistance properties and values of average \pm one standard deviation are reported.

The morphology of the composites was observed using an SEM instrument (Hitachi S 3000 N). Samples were sputter-coated with gold palladium and observed using a voltage of $20 \mathrm{kV}$.

\section{Results and Discussion}

\section{Fiber characterization}

\section{Fiber composition and physical structure}

The properties of the milkweed fibers used as reinforcement in the composites are given in Table 1. The milkweed floss fibers have a low cellulose content of about $52 \%$ compared to kenaf fibers. However, unlike kenaf fibers that have been extracted by natural retting or chemical processes, the milkweed fibers are in their native form. If necessary, the milkweed fibers can be chemically treated to remove the non-cellulosic substances and obtain fibers with high cellulose contents. Although milkweed floss is a single-cell fiber, it has relatively high amounts of lignin compared to kenaf. Previous studies on characterizing various varieties of milkweed fibers have also reported similar composition of cellulose and lignin. ${ }^{7,} 16$

Milkweed floss has relatively short lengths compared to any other natural cellulose fibers in commercial use. The short length of the fibers makes it difficult for them to be processed as more common fibers and would also result in composites with inferior mechanical properties if all other fiber properties remain the same. However, milkweed floss has been reported to have lengths up to $30 \mathrm{~mm}^{7,16}$ Milkweed floss also has a low percentage crystallinity compared to jute, linen and other cellulose fibers. However, the low cellulose content and percentage crystallinity should contribute to the low density of the floss fibers. In a study on developing textiles from milkweed floss, it has been reported that milkweed floss has a crystallinity of about $73 \%$ compared to about $90 \%$ for cotton. ${ }^{15}$ Generally, the percentage crystallin- ity of cellulose fibers such as cotton, jute and flax is about $65-70 \%$, whereas some natural cellulose fibers obtained from agricultural byproducts have crystallinities of about $35-50 \% .{ }^{18-23}$ The moisture regain of milkweed floss is higher than that of kenaf fibers and the density of the milkweed floss is $0.893 \mathrm{~g} \mathrm{~cm}^{-3}$.

\section{Fiber morphology}

Figures 2 and 3 show the longitudinal and cross-sectional morphologies, respectively, of the milkweed floss fibers. As can be seen in Figure 2, the fibers are unicellular and have a smooth surface. Most of the fibers are cylindrical but some are ribbon-like and are twisted. The fibers do not have the convolutions seen in cotton. The floss fibers have a completely hollow cross-section with a relatively thin cell wall, as seen in Figure 3. The hollow center provides the fibers with good insulation properties but may cause the fibers to be brittle. Overall, milkweed floss has a unique morphology not found in the more commonly used natural cellulose fibers.

\section{Composite characterization}

\section{Morphology of composites}

The morphologies of the milkweed/PP composites are shown in Figures 4 and 5 and those of the kenaf composites in Figures 6 and 7 . At 35\% milkweed and composite density of $1000 \mathrm{~g} \mathrm{~m}^{-2}$, there is a uniform distribution of the milkweed from the edge to the center of the composite, as seen in Figure 4 . There are considerable voids between the reinforcing fibers since the density of the composite is low. The unique hollow cross-section of the milkweed floss is intact even after formation of the composites. Increasing the amount of milkweed to $50 \%$ and the density of the composite to $2000 \mathrm{~g} \mathrm{~m}^{-2}$ eliminates most of the voids in the composites resulting in a dense, tight structure, as seen in Figure 5. Such a composite will have better mechanical properties than the low-density composites as will be discussed later.

The $35 \%$ kenaf composites also have a considerable amount of voids, as seen in Figure 6 . Increasing the concentration of the kenaf fibers in the composite to $50 \%$ decreases the number of voids, as seen in Figure 7, and hence improves

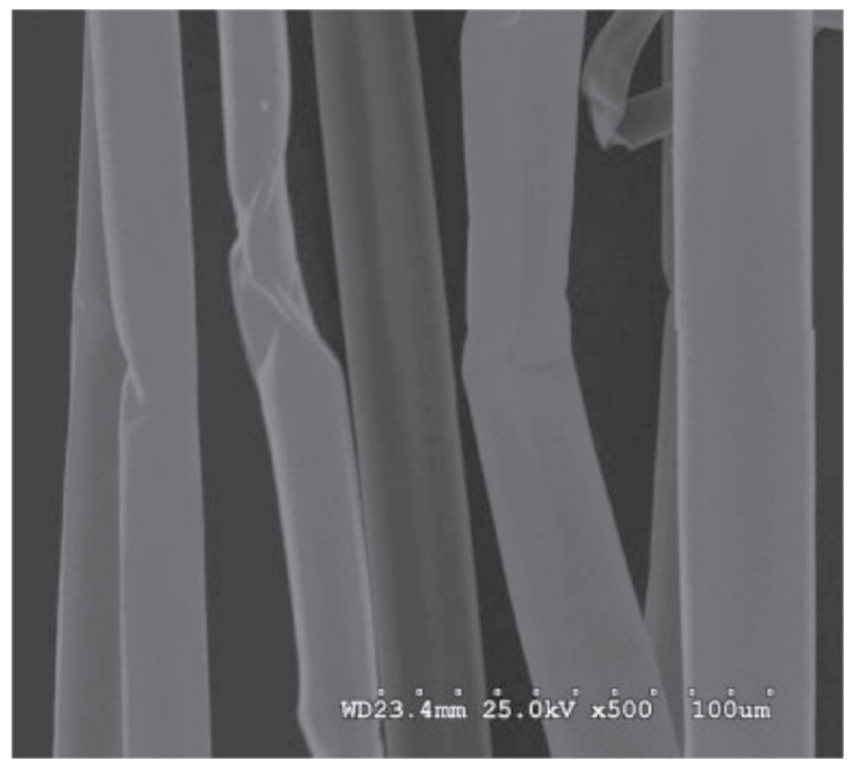

Figure 2. SEM image showing the longitudinal features of the milkweed floss fibers. The fibers have a smooth surface and are mostly cylindrical with some twists. 


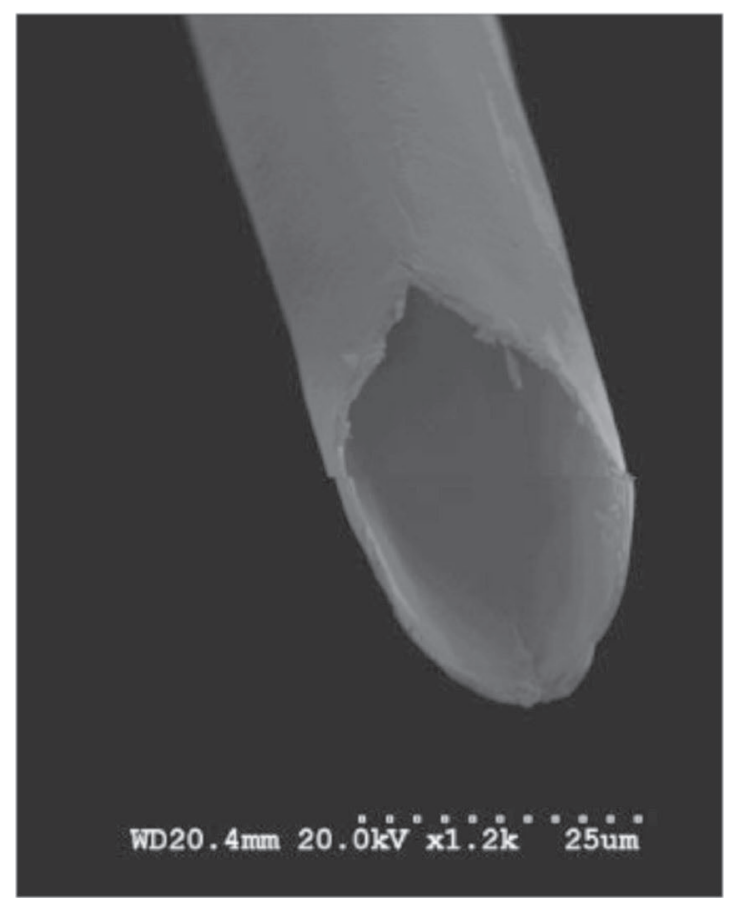

Figure 3. SEM image depicting the unique hollow center and thin cell wall of a milkweed floss fiber.

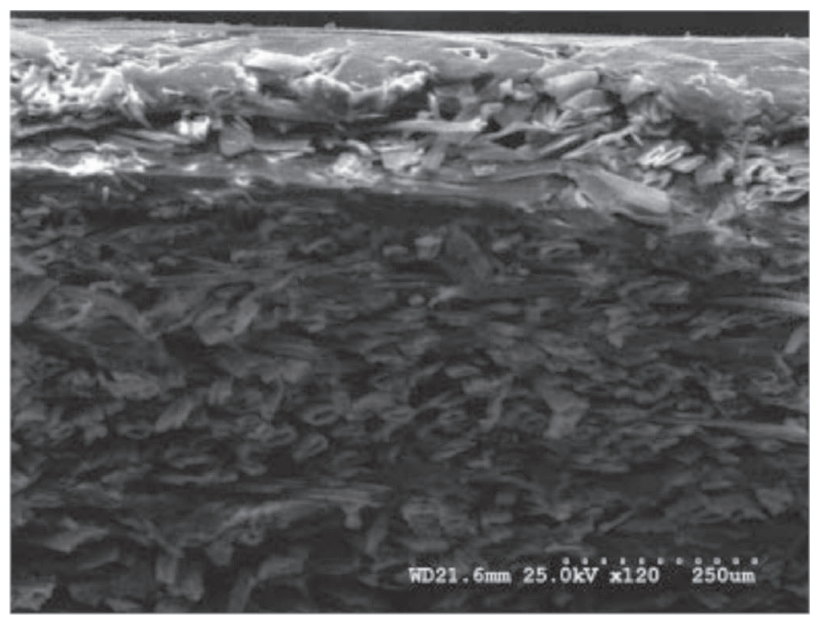

Figure 4. SEM image of the $35 / 65$ (w/w) milkweed/PP composite with a density of $1000 \mathrm{~g} \mathrm{~m}^{-2}$. The milkweed floss is evenly distributed from the edge to the center of the composite and the hollow centers in the milkweed floss and the voids between the fibers are visible.

the flexural and tensile properties. However, the $50 \%$ kenaf composite has a larger number of voids than the milkweed composites because of the higher density of the kenaf fibers, and hence has smaller amounts of fibers in the composite with the same density and thickness.

\section{Flexural properties of composites reinforced with $35 \%$ milkweed}

The effect of increasing the density of the composites made from $35 \%$ milkweed and $65 \%$ PP on the flexural properties is shown in Figure 8. Increasing the density of the composites improves all the composite properties investigated. At densities of 1000 and $1300 \mathrm{~g} \mathrm{~m}^{-2}$, the composites have poor properties since there is not sufficient material to fill the thickness of the composite and the composites have large num-

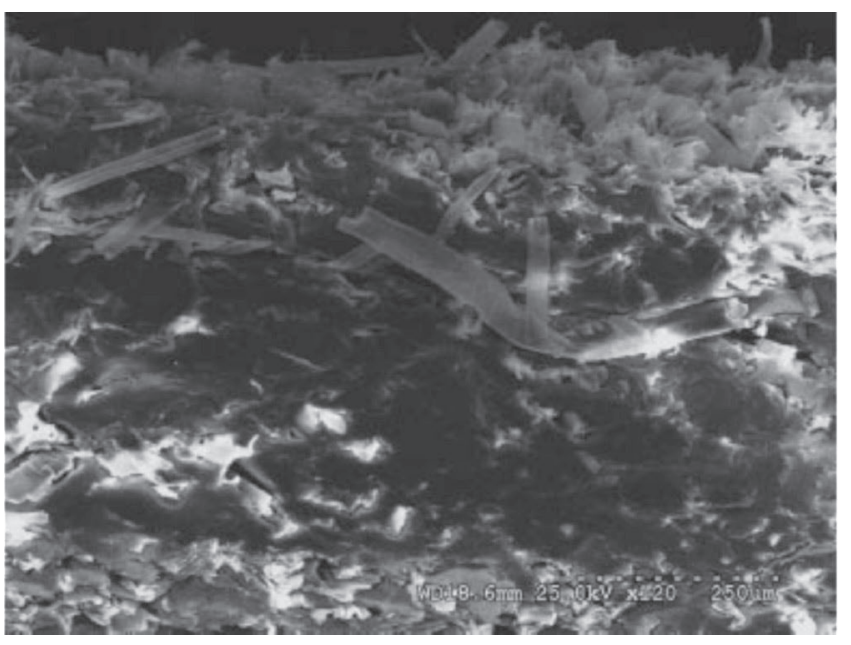

Figure 5. SEM image of the 50/50 (w/w) milkweed/PP composite with a density of $2000 \mathrm{~g} \mathrm{~m}^{-2}$. The composite is compact with fewer voids compared to the lower density composite.

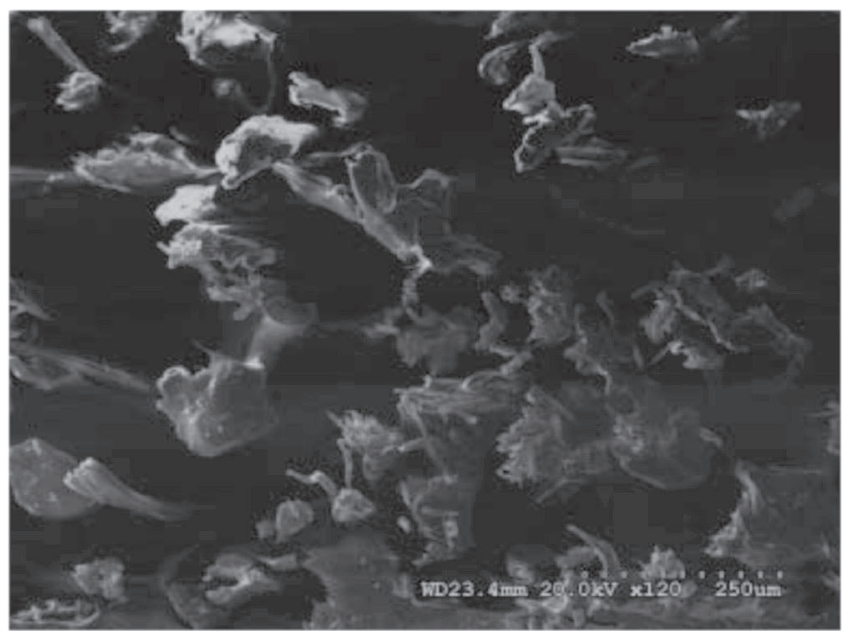

Figure 6. SEM image of the $35 / 65(\mathrm{w} / \mathrm{w})$ kenaf/PP composite with a density of $1300 \mathrm{~g} \mathrm{~m}^{-2}$ showing the presence of considerable amounts of voids compared to the milkweed composite.

ber of voids that will lead to poor flexural properties. Increasing the density of the composites to 1700 and $2000 \mathrm{~g} \mathrm{~m}^{-2}$ significantly improves some of the properties of the composites. There is an about $100 \%$ increase in the flexural strength of the composites when the density is increased from 1300 to $1700 \mathrm{~g} \mathrm{~m}^{-2}$ and about $50 \%$ increase when the density is increased from 1700 to $2000 \mathrm{~g} \mathrm{~m}^{-2}$. The modulus of elasticity also shows a sharp increase of about $50 \%$ when the density is increased to 2000 from $1700 \mathrm{~g} \mathrm{~m}^{-2}$. The offset yield load, stiffness and maximum load show a gradual increase with increasing composite density.

The improvement in the flexural properties of the composites with increasing density should mainly be for two reasons. Since the thickness of the composites is kept constant, increasing the amount of fibers will inevitably decrease the voids in the composites which will lead to better flexural properties. At high densities, the composites are tightly packed with minimum voids and therefore the composites have good flexural properties. The properties of the reinforcing fiber, in this case milkweed floss, also play a critical role in determining the properties of the composites. Milkweed floss has 


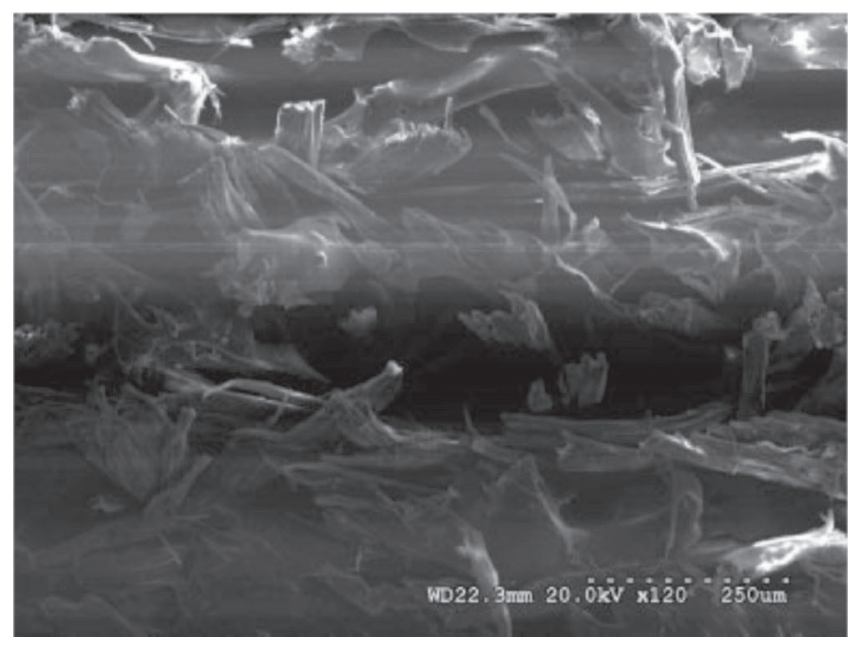

Figure 7. SEM image of the 50/50 (w/w) kenaf/PP composite with a density of $1300 \mathrm{~g} \mathrm{~m}^{-2}$ showing the presence of fewer voids compared to the $35 \%$ kenaf composite.

relatively low breaking elongation (1-2\%) compared to the textile fibers commonly used as reinforcements in composites. Therefore, composites reinforced with milkweed can be expected to have higher stiffness and modulus of elasticity compared to composites reinforced with fibers that have high elongations.

\section{Flexural properties of composites reinforced with $50 \%$ milkweed}

The effect of increasing the density of the composites reinforced with $50 \%$ milkweed on the flexural properties is shown in Figure 9. Unlike increasing density for composites reinforced with $35 \%$ milkweed where the properties improve with increasing density, the flexural properties become poorer at high densities when reinforced with $50 \%$ milkweed. Increasing the density of the composite from 1000 to $1300 \mathrm{~g} \mathrm{~m}^{-2}$ and from 1300 to $1700 \mathrm{~g} \mathrm{~m}^{-2}$ improves all the flexural properties in Figure 9. However, increasing the density from 1700 to $2000 \mathrm{~g} \mathrm{~m}^{-2}$ does not improve the flexural properties, and in fact the flexural strength slightly decreases. The improvement in the properties of the composites with increasing rein- forcement content should mainly be due to the decrease in the number of voids. However, at high concentrations of milkweed, the amount of PP in the composites is insufficient to bind the fibers leading to poor interaction between the reinforcing and matrix materials and therefore to poorer flexural properties.

\section{Tensile properties: effect of increasing the density of composites}

The effect of increasing the density of composites containing two levels of milkweed floss on the tensile strength and modulus is given in Table 2. As is evident, increasing the density improves the strength and modulus for composites reinforced with both 35 and $50 \%$ milkweed except for the strength of the $2000 \mathrm{~g} \mathrm{~m}^{-2}$ composite with $35 \%$ milkweed. As for the flexural properties, increasing the density decreases the voids and therefore provides better tensile properties. A large improvement in the tensile properties of the composites is seen when the density is increased from 1300 to 1700 $\mathrm{g} \mathrm{m}^{-2}$, especially for the composite with $35 \%$ milkweed, indicating that an optimum level of reinforcing material is necessary to obtain good tensile properties.

Tensile properties: effect of increasing the proportion of milkweed in composites

Increasing the proportion of milkweed decreases the tensile strength of the composites except for the composite with a density of $1000 \mathrm{~g} \mathrm{~m}^{-2}$, as is evident from Table 2. The 1000 $\mathrm{g} \mathrm{m}^{-2}$ composite with $50 \%$ milkweed has about $75 \%$ higher tensile strength than the $35 \%$ milkweed composites. Further increase in the density of the composites with $50 \%$ milkweed decreases the tensile strength compared to the $35 \%$ milkweed composites. PP composites with $50 \%$ milkweed and a density of $1700 \mathrm{~g} \mathrm{~m}^{-2}$ have about $50 \%$ of the tensile strength of the $35 \%$ milkweed composites at the same density.

The tensile modulus of the composites shows considerably less variation with increasing milkweed content compared to the changes in the tensile strength. In fact, increasing the amount of milkweed from 35 to $50 \%$ increases the tensile modulus of the composites except for the composite with a density of $1300 \mathrm{~g} \mathrm{~m}^{-2}$. A large increase in modulus $(70 \%$ higher) is seen when the density of the composites is increases from 1000 to $1300 \mathrm{~g} \mathrm{~m}^{-2}$ for the $35 \%$ milkweed

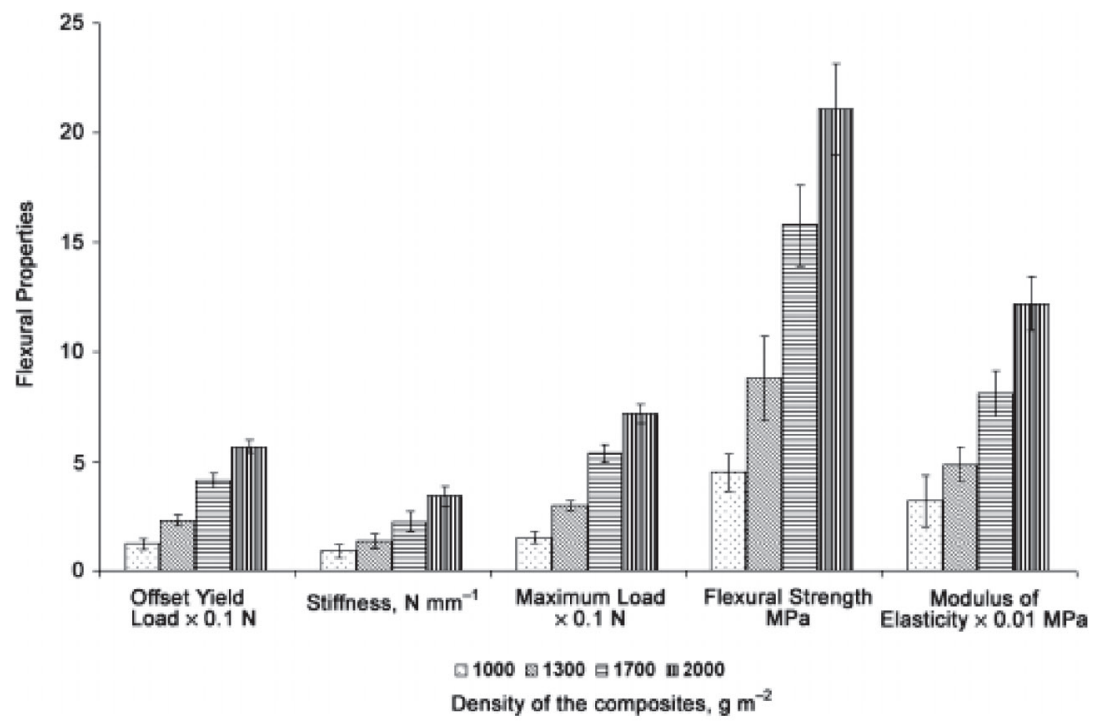

Figure 8. Flexural properties of the 35/65 (w/w) milkweed/PP composites at four densities. The composites were fabricated by compression molding at a temperature of $380^{\circ} \mathrm{F}$ for $140 \mathrm{~s}$, having a thickness of $3.2 \mathrm{~mm}$. 


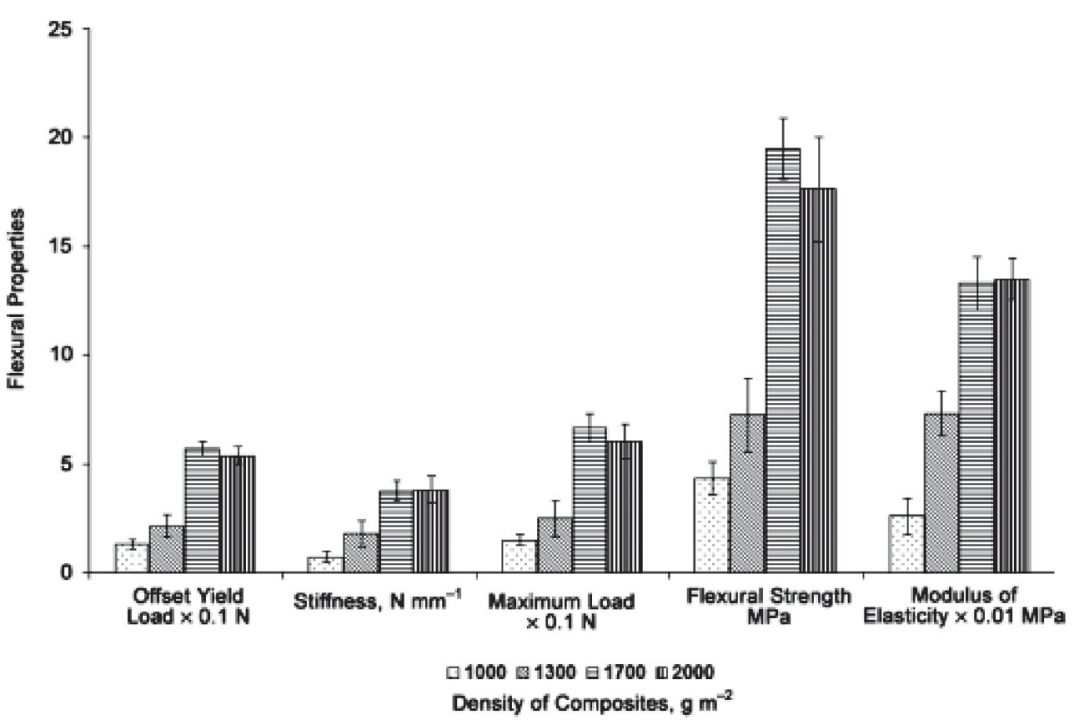

Figure 9. Flexural properties of the 50/50 (w/w) milkweed/PP composites at four densities. The composites were fabricated by compression molding at a temperature of $380^{\circ} \mathrm{F}$ for $140 \mathrm{~s}$, having a thickness of $3.2 \mathrm{~mm}$.

Table 2. Tensile properties of milkweed-reinforced PP composites for various densities and two proportions (35/65 and 50/50) of milkweed/PP

\begin{tabular}{lccccc}
\hline \multirow{2}{*}{$\begin{array}{l}\text { Density } \\
\left(\mathrm{g} \mathrm{m}^{-3}\right)\end{array}$} & \multicolumn{2}{c}{ Strength $(\mathrm{MPa})$} & & \multicolumn{2}{c}{ Modulus $(\mathrm{GPa})$} \\
\cline { 2 - 3 } \cline { 6 - 6 } & $35 / 65$ & $50 / 50$ & & $35 / 65$ & $50 / 50$ \\
\hline 1000 & $15.5 \pm 4.9$ & $27.1 \pm 4.4$ & & $2.2 \pm 0.4$ & $2.6 \pm 0.7$ \\
1300 & $37.7 \pm 6.9$ & $28.8 \pm 5.4$ & & $3.7 \pm 0.4$ & $2.9 \pm 0.8$ \\
1700 & $69.4 \pm 6.5$ & $33.3 \pm 9.1$ & & $3.8 \pm 6.0$ & $4.4 \pm 0.5$ \\
2000 & $60.1 \pm 7.0$ & $44.6 \pm 7.4$ & & $4.5 \pm 0.4$ & $4.7 \pm 0.6$ \\
\hline
\end{tabular}

composites. A similar increase (50\% higher) in tensile modulus is also seen for the $50 \%$ milkweed composites but when the density is increased from 1300 to $1700 \mathrm{~g} \mathrm{~m}^{-2}$.

The extent of improvement in the tensile properties of the composites with increasing proportion of milkweed will be governed by the properties of the fibers and by the interaction between the reinforcing and matrix materials. The inferior properties of the composites with $50 \%$ milkweed composites compared to those with $35 \%$ milkweed should mainly be due to insufficient PP to bind the milkweed fibers.

\section{Impact resistance properties}

The impact resistance of the composites with two proportions of milkweed and various composite densities is shown in Figure 10. The composites with a density of $1000 \mathrm{~g} \mathrm{~m}^{-2}$ have lower impact resistance than those with higher densities. The impact resistance increases substantially when the density is increased from 1000 to $1300 \mathrm{~g} \mathrm{~m}^{-2}$ for both the 35 and $50 \%$ milkweed composites. The 50/50 milkweed/PP composite has slightly better impact resistance than the 35/65 milkweed/PP at densities of 1000 and $1300 \mathrm{~g} \mathrm{~m}^{-2}$. The impact resistance of the 35/65 milkweed/PP composite slightly improves with increasing density but that of the $50 / 50$ composite remains the same for densities of 1300,1700 and $2000 \mathrm{~g} \mathrm{~m}^{-2}$.

At low density $\left(1000 \mathrm{~g} \mathrm{~m}^{-2}\right.$ ), there is not enough material in the composite to bear the impact and therefore the composite has low impact resistance. Increasing the density of the composite will add more material, decrease the voids and therefore improve the impact resistance. At 35\% milk- weed in the composite, increasing density reduces the voids and therefore the impact resistance slightly improves with increasing density. At 50\% milkweed in the composite and $1300 \mathrm{~g} \mathrm{~m}^{-2}$, there is enough material in the composite and a further increase in the weight of the composite does not improve the impact resistance.

\section{Comparison of properties of milkweed fiber- and kenaf fiber-reinforced PP composites}

Table 3 provides a comparison of the properties of the milkweed floss-reinforced PP composites with similar PP composites reinforced with kenaf fibers. As is evident, the milkweed composites have much higher flexural and tensile properties compared to the kenaf composites. The $35 \%$ milkweed-reinforced composites have 125\% higher flexural strength than the $35 \%$ kenaf-reinforced composites and the $50 \%$ milkweed composites have nearly twice the flexural strength of the $50 \%$ kenaf composites. The moduli of elasticity of the 35 and $50 \%$ milkweed composites are also higher by nearly 2.5 and nearly 5 times compared to the respective kenaf composites. Tensile strengths of the milkweed composites are also higher by about 140 and $73 \%$ for 35 and $50 \%$ milkweed contents, respectively. Tensile moduli of the milkweed-reinforced composites are higher by 80 and $65 \%$ for the 35 and $50 \%$ milkweed composites, respectively. The impact resistance of the $35 \%$ milkweed composite is similar to that of the $50 \%$ kenaf composite and the $50 \%$ milkweed composite has an impact resistance similar to that of the $35 \%$ kenaf composite. The better flexural and tensile properties of the milkweed composites are mainly due to the lower density and therefore higher amounts of milkweed in the composites. Higher amounts of milkweed will reduce the voids between the reinforcing and matrix materials and therefore provide the composites with better properties.

\section{Conclusions}

Lightweight PP composites reinforced with milkweed fibers show much better flexural and tensile properties than similar PP composites reinforced with kenaf fibers. Milkweed floss has a low cellulose and high lignin content and low percentage crystallinity compared to kenaf fibers. Milkweed floss 


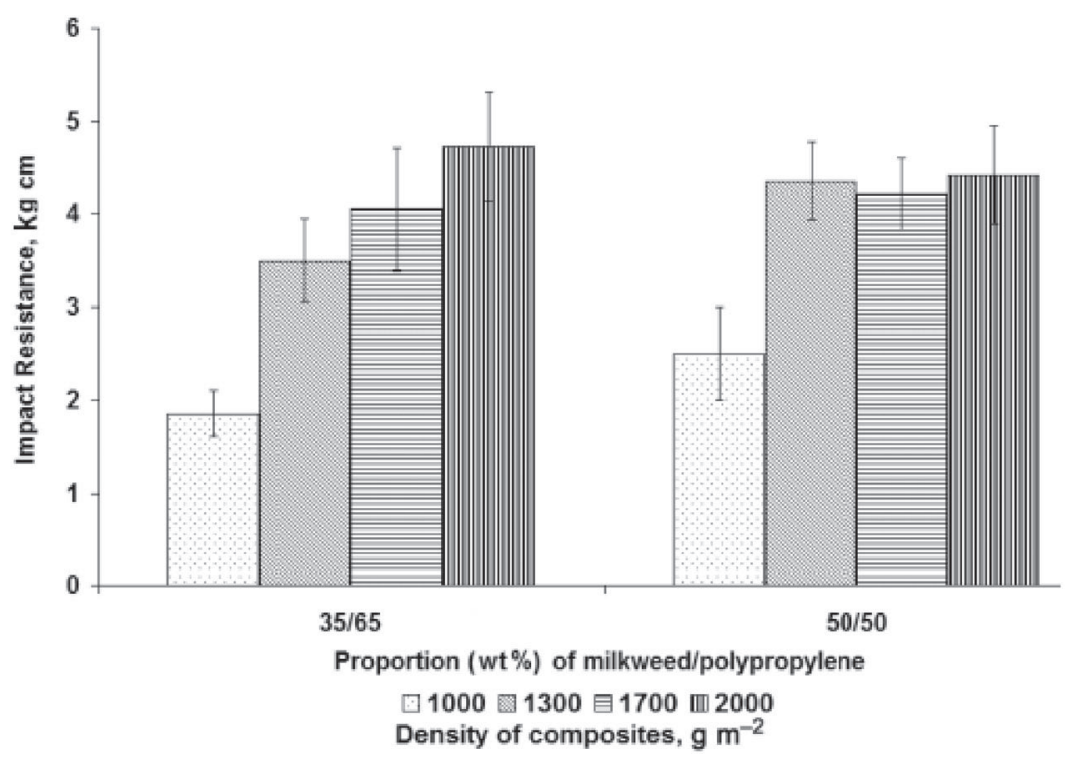

Figure 10. Impact resistance of milkweed/PP composites at four densities and two proportions of milkweed floss. The composites were fabricated by compression molding at a temperature of $380^{\circ} \mathrm{F}$ for $140 \mathrm{~s}$, having a thickness of $3.2 \mathrm{~mm}$.

Table 3. Comparison of flexural and tensile properties of milkweed-reinforced PP composites with similar kenaf-reinforced PP composites

\begin{tabular}{|c|c|c|c|c|c|}
\hline Composite $^{a}$ & $\begin{array}{l}\text { Flexural } \\
\text { strength } \\
\text { (MPa) }\end{array}$ & $\begin{array}{l}\text { Modulus } \\
\text { of } \\
\text { elasticity }\end{array}$ & $\begin{array}{l}\text { Tensile } \\
\text { strength } \\
\text { (MPa) }\end{array}$ & $\begin{array}{l}\text { Tensile } \\
\text { modulus } \\
\text { (GPa) }\end{array}$ & $\begin{array}{l}\text { Impact } \\
\text { resistance } \\
(\mathrm{kg} \mathrm{cm})\end{array}$ \\
\hline Milkweed/PP (35/65) & $15.8 \pm 1.9$ & $811 \pm 104$ & $37.7 \pm 4.9$ & $3.6 \pm 0.4$ & $3.5 \pm 0.4$ \\
\hline Kenaf/PP (35/65) & $7.0 \pm 2.6$ & $326 \pm 104$ & $15.6 \pm 1.7$ & $2.0 \pm 0.5$ & $4.7 \pm 0.3$ \\
\hline Kenaf/PP (50/50) & $6.6 \pm 3.0$ & $270 \pm 111$ & $18.3 \pm 1.5$ & $2.3 \pm 0.2$ & $3.3 \pm 1.0$ \\
\hline
\end{tabular}

a. The composites had a weight per unit area of $1300 \mathrm{~g} \mathrm{~m}^{-2}$ and a thickness of $3.2 \mathrm{~mm}$ and were fabricated by compression molding at $380{ }^{\circ} \mathrm{F}$ for $140 \mathrm{~s}$.

fibers have short lengths and low elongation but are completely hollow unlike any other natural cellulose fibers. The presence of a hollow center and perhaps low crystallinity provides milkweed fibers with low density. The low density of milkweed fibers allows larger amounts of the fibers per unit weight of a composite leading to fewer voids and hence better flexural and tensile properties. The research presented shows that low-density reinforcing materials are preferable for developing lightweight composites.

Acknowledgments - The authors thank the Agricultural Research Division at the University of Nebraska-Lincoln, USDA Hatch Act, and Multistate Research Project S-1026 for their financial support to complete this work.

\section{References}

1 Mohanty AK, Misra M, and Hinrichsen G, Macromol Mater Eng 276/277:1-24 (2000).

2 Huda S and Yang Y, Macromol Mater Eng 293:235-243 (2008). 3 Huda S and Yang Y, Compos Sci Technol 68:790-798 (2008).

4 Huda S and Yang Y, Ind Crop Prod 30:17-23 (2009).

5 Huda S and Yang Y, J Polym Environ 17:131-142 (2009).

6 Reddy N and Yang Y, Biores Technol 100:3563-3569 (2009).

7 Sakthivel JC, Mukhopadhyay S, and Palanisamy NK, J Ind Text 35:63-76 (2005).

8 Shakyawar DB, Dagur RS, and Gupta NP, Indian J Fibre Text Res 24:264-268 (1999).

9 Crews PC, Sievert S, and Woeppel LT, Text Res J 61:203-210 (1991).

10 Forman LV and Niemeyer D, Paper Trade J 121:29-34 (1945).
11 Knudsen HD and Zeller RD, The milkweed business, in New Crops, ed. by Janick J and Simon JE. Wiley, New York, pp. 422-428 (1993).

12 Ronald H and Rogers HK, Fuel 85:2106-2110 (2006).

13 Witt MD and Knudsen HD, Milkweed cultivation for floss production, in New Crops, ed. by Janick J and Simon JE. Wiley, New York, pp. 428-431 (1993).

14 Drean JF, Patry JJ, Lombard GF, and Weltrowski M, Text Res J 63:443-450 (1993).

15 Louis GL and Andrews BAK, Text Res J 57:339-345 (1987).

16 Nourbakhsh A, Ashori A, and Kouhpayehzadeh M, J Reinf Plast Compos 28:2143-2149 (2009).

17 Weaver J, Analytical Methods for a Textile Laboratory, 3rd edition. American Association of Textile Chemists and Colorists, Research Triangle Park, NC, pp. 11-27 (1984).

18 Reddy N and Yang Y, Green Chem 7:190-195 (2005).

19 Reddy N and Yang Y, J Agric Food Chem 54:8077-8081 (2006).

20 Reddy N and Yang Y, J Agric Food Chem 55:8570-8575 (2007).

21 Reddy N and Yang Y, Biotechnol Bioeng 97:1021-1027 (2007).

22 Reddy N and Yang Y, J Agric Food Chem 55:5569-5574 (2007).

23 Reddy N and Yang Y, Biores Technol 99:2449-2454 (2008).

24 Morrison WH, Akin DE, Ramaswamy G, and Baldwin B, Text Res J 66:651-656 (1996).

25 Tao W, Calamari TA, and Crook L, Text Res J 68:402-406 (1998).

26 Tao W, Calamari TA, Yu C, and Chen Y, Text Res J 69:720-724 (1999). 